Vandecta

\title{
Penegakan Hukum Terhadap Warga Negara Asing (WNA) yang Melanggar Izin Tinggal (Overstay)
}

\author{
Desi Setiawati $^{\bowtie}$
}

Fakultas Hukum Universitas Negeri Semarang, Indonesia

Permalink/DOI http://dx.doi.org/10.15294/pandecta.v9i1.

\section{Info Artikel}

Sejarah Artikel:

Diterima October 2014

Disetujui November 2014

Dipublikasikan January 2015

\section{Keywords:}

Foreigner;

Semarang Immigra-

tion Office Class

\begin{abstract}
Abstrak
Keindahan alam Indonesia menjadi daya tarik bagi wisatawan asing yang berkunjung ke Indonesia, namun demikian tidak sedikit warga negara asing (WNA) melakukan pelanggaran terkait keimigrasian di Indonesia salah satunya melanggar batas waktu izin tinggal (overstay). Penelitian ini bertujuan untuk mengetahui dan menganalisis penegakan hukum terhadap warga negara asing (WNA) yang melanggar izin tinggal (overstay) dan untuk mengetahui dan menganalisis faktor-faktor yang mempengaruhi penegakan hukumnya. Jenis penelitian ini menggunakan yuridis sosiologis dan menggunakan metode pendekatan kualitatif. Data penelitian diperoleh melalui wawancara, sedangkan proses pengolahan data melalui pengumpulan data, penyajian data, analisis data, dan kesimpulan. Penegakan hukum di Kantor Imigrasi Kelas I Semarang dilakukan dengan tahap pengawasan dan penindakan. Pengawasan terhadap warga negara asing (WNA) di Indonesia dilakukan dengan 2 tahap, yaitu pemeriksaan data administratif dan pengawasan di lapangan. Penindakan dilakukan kepada WNA dengan memberikan pengenaan biaya beban atau deportasi. Faktor Pendukungnya adalah Kantor Imigrasi Kelas I Semarang bekerja sama dengan instansi terkait seperti Kepolisian Daerah Jawa Tengah, Polrestabes Semarang beserta jajarannya, dan partisipasi masyarakat serta aktifnya penjamin dalam mempertanggung jawabkan keberadaan dan kegiatan warga negara asing (WNA). Faktor Penghambatnya adalah jarak tempuh yang sangat jauh untuk menjangkau seluruh wilayah kerja Kantor Imigrasi Kelas I Semarang, dan jumlah tim penegak hukum di Kantor Imigrasi Kelas I Semarang yang kurang memadai.
\end{abstract}

\begin{abstract}
The beauty Indonesian nature become fascination for foreigner to visit Indonesia, but some of foreigner break the rule about immigration in Indonesia, one of them is overstayed. The purposes of the research are to understand and analyze the law enforcement to foreigner who overstay and to understand and analyze the factors affecting of law enforcement. The research uses Socio-juridical and analyzed using qualitative methods. The research data obtained through an interview and data processing through data collection, data presentation, data analysis, and conclusions. The law enforcement in Semarang Immigration Office Class I done in supervision and enforcement. The supervision to foreigner in Indonesia were done in 2 (two) stages, they are inspection of administrative and supervision in the real. The enforcement are pay a fine and deportation that give to foreigner. The contributing factors are collaborate between Semarang Immigration Office Class I and relevant agencies such as Central Java Regional Police, Police Major Resort City of Semarang, society's participation and guarantor's active to account for the presence and activities of foreigner. Obstacle factors are the long distance to get the working area of Semarang Immigration Office Class I, and the number of law enforcement teams in Semarang Immigration Office Class I inadequate.
\end{abstract}

$\triangle$ Alamat korespondensi:

Kampus Sekaran, Gedung K1, Gunungpati Semarang

Jawa Tengah, Indonesia 50229

Email: setiawatidesi6@gmail.com
(C) 2015 Universitas Negeri Semarang ISSN 1907-8919 (Cetak) ISSN 2337-5418 (Online) 


\section{Pendahuluan}

Negara Indonesia yang berwilayah dari Sabang sampai Merauke merupakan salah satu negara yang subur, kaya akan sumber daya alam seperti bahan baku dan rempahrempah, serta memiliki potensi alam berupa daratan dan lautan untuk dieksplorasi, sehingga mengakibatkan banyak wisatawan asing untuk berkunjung maupun bekerja di Indonesia (Sjahriful, 1993:8).

Keindahan alam Indonesia yang menjadi daya tarik bagi wisatawan asing untuk berkunjung ke Indonesia mengakibatkan banyaknya pelancong asing yang melakukan pelanggaran di Indonesia. Contoh pelanggaran keimigrasian pada tahun 2014 yang dilakukan oleh orang asing yang masa berlaku izin tinggalnya telah habis dan masih berada di wilayah Semarang (overstay) bernama Daboba Akrem Husein Mohamed Milaad, seorang berkebangsaan Libya yang selama lebih dari 60 (enam puluh) hari atau tepatnya 154 (seratus lima puluh empat) hari dari batas waktu izin tinggalnya di Indonesia. Daboba Akrem Husein Mohamed Milaad mengetahui bahwa izin tinggalnya telah habis sejak awal bulan November, namun Milaad mengalami kecelakaan pada 14 Juni 2014 sehingga Milaad harus dirawat dan di Operasi di Rumah Sakit Telogorejo Semarang selama 3 bulan. Pelanggaran ini dikenakan Pasal 124 Undang-Undang Nomor 6 Tahun 2011 yaitu dilakukan sanksi Administratif berupa Deportasi dan mengusulkan namanya pada daftar Penangkalan (Kantor Imigrasi Kelas I Semarang, 2014).

Terkait dengan pelanggaran izin tinggal menurut Okky Setiawan Kasubsi Penindakan Kantor Imigrasi Kelas I Semarang menjelaskan pelanggaran izin tinggal terbagi dalam 3 jenis, yaitu penyalahgunaan izin tinggal, melebihi batas waktu izin tinggal (overstay), dan tidak memiliki izin tinggal (illegal stay) (Wawancara, 9 Januari 2015).

Pejabat Imigrasi berwenang melakukan tindakan kepada orang asing yang melanggar izin tinggal dengan tindakan administratif keimigrasian, sedangkan kejahatan pidana dan narkoba diselesaikan di pengadilan (pro justicia) disidik oleh Penyidik Pegawai Negeri
Sipil (PPNS) Keimigrasian (Wawancara, 9 Januari 2015).

Pengawasan yang dilakukan oleh Kantor Imigrasi dilakukan dengan 2 tahap. Tahap pertama yaitu tahap administrasi dengan memeriksa data orang asing yang melanggar izin tinggal dan tahap kedua adalah pengawasan di lapangan. Pengawasan di lapangan bersumber dari pemeriksaan administrarif, dan dikeluarkan berdasarkan Surat Perintah dari Kantor Imigrasi, keberadaan Orang Asing yang berkaitan dengan alamat izin tinggal serta kegiatan Orang Asing selama tinggal di wilayah Indonesia (Wawancara dengan Kasubsi Penindakan, Okky Setyawan 9/1/2015).

Menurut Safaat (2008:112) untuk mewujudkan sistem penegakan hukum keimigrasian memerlukan adanya substansi hukum, dalam hal ini Undang-Undang Nomor 9 Tahun 1992 tentang Keimigrasian dan Undang-Undang Nomor 8 Tahun 1981 tentang Hukum Acara Pidana. Selain itu, struktur hukum dalam hal ini organisasi, infrastruktur, dan sumber daya manusia penegakan hukum keimigrasian, dan budaya hukum baik dalam hukum ataupun pada masyarakat secara luas. Munculnya kendala-kendala di dalam penegakan hukum keimigrasian dikarenakan tidak sinkronnya masing-masing sub sistem di dalam sistem penegakan hukum keimigrasian, hal ini dapat diminimalisir dengan adanya sinkronisasi aturan substansi hukum yang bersifat lex specialis dengan aturan substansi hukum yang bersifat lex generalis untuk meningkatkan sistem penegakan hukum keimigrasian.

Penegakan hukum keimigrasian lebih dititikberatkan pada tindakan administratif keimigrasian. Menurut Eka Rendytia Faizal (2013:90) dalam penelitiannya menyimpulkan bahwa kendala yang ada di Kantor Wilayah Kementerian Hukum dan HAM Jawa Tengah dalam melaksanakan pengawasan dan penindakan keimigrasian terhadap orang asing diantaranya yaitu (a) kurangnya kualitas dan kuantitas sumber daya manusia pegawai Kantor Wilayah Kementerian Hukum dan HAM Jawa Tengah dan jajaran unit pelaksana teknis; (b) anggaran kerja untuk kegiatan pengawasan dan penindakan orang asing 
tidak aplikatif dengan rencana kerja (Faizal,2013:90).

Kendala-kendala tersebut juga terjadi di daerah lainnya di Indonesia. Menurut Robiyansah dalam penelitiannya (2012:101) mengatakan bahwa faktor-faktor yang mempengaruhi pengawasan izin tinggal terhadap tenaga kerja asing khususnya di wilayah kerja Imigrasi Samarinda adalah anggaran dana operasional pengawasan yang tidak sesuai, kurangnya kualitas dan kuantitas petugas/ pejabat/aparatur imigrasi sebagai PPNS, sarana dan prasarana yang memadai, serta sponsor dan tenaga kerja asing itu sendiri dalam menaati aturan keimigrasian dan peran serta masyarakat maupun pemerintah pusat dan daerah dalam penegakan hukum keimigrasian dan pengawasan wilayah kerja Kantor Imigrasi Kelas I Samarinda yang luas terdiri dari 3 Kabupaten dan 2 Kota (Robiyansah,2012:101).

\section{Metode Penelitian}

Pendekatan penelitian kualitatif hukum dengan jenis penelitian yuridis sosiologis (Amiruddin, 2012). Lokasi penelitian di Kantor Imigrasi Kelasl Semarang. Fokus penelitian pada penegakan hukum di Kantor Imigrasi Kelas I Semarang terhadap warga negara asing (WNA) yang melanggar izin tinggal (overstay) dan faktor-faktor yang mempengaruhi penegakan hukumnya. Jenis data dalam penelitian ini menggunakan data primer dan data sekunder dengan menggunakan metode wawancara. Teknik analisis data yang digunakan yaitu penelitian hukum sosiologis. Penelitian ini dilakukan dengan mengkaji bahan-bahan hukum yang berkaitan dengan penegakan hukum terhadap warga negara asing (WNA) yang melanggar izin tinggal di Indonesia khususnya di Kota Semarang, yang dikaitkan dengan bagaimana penerapan aturan hukum tersebut di masyarakat. Analisis mengenai permasalahan yang diangkat dalam penelitian ini, dilakukan dengan cara menganalisis permasalahan yang ada di lapangan yakni mengenai pelaksanaan Undang-Undang Nomor 6 Tahun 2011 di Kantor Imigrasi Kelas I Semarang. Selanjutnya dikaji dalam peraturan perundang-undangan yang berlaku. Setelah analisis data selesai, maka hasilnya disajikan secara deskriptif, yaitu dengan menuturkan dan menggambarkan apa adanya sesuai dengan permasalahan yang diteliti. Berdasarkan hasil tersebut kemudian ditarik kesimpulan yang merupakan jawaban atas permasalahan yang diangkat dalam penelitian ini (Amiruddin, 2013).

\section{Hasil Penelitian dan Pembahasan}

\section{a. Deskripsi Warga Negara Asing (WNA) di Kota Semarang}

Semarang adalah ibu kota dari Provinsi Jawa Tengah dan termasuk dalam jajaran kota-kota besar yang ada di Indonesia. Sebagai salah satu kota besar, keberadaan kota Semarang seolah terlupakan. Semarang seolah ditutupi oleh bayang-bayang kota besar lainnya seperti Jakarta dan Surabaya. Banyak masyarakat Indonesia tidak mengetahui akan potensi yang dimiliki oleh Semarang, dan dalam hal ini adalah kekayaan seni budaya. Semarang memiliki banyak kekayaan, khususnya dalam hal kesenian dan budaya. Tidak aneh jika Semarang mendapat julukan "The Beauty of Asia" atau Semarang Pesona Asia, karena potensi-potensi yang dimilikinya (Linardi, 2013:1).

Banyaknya potensi wisata yang ada di Semarang, menyebabkan WNA datang ke Semarang dan tinggal sementara waktu atau menetap di Kota Semarang, baik untuk bekerja dan berkunjung. Seiring berjalannya waktu, jumlah orang asing yang datang ke Semarang setiap tahunnya bertambah. Untuk mengetahui jumlah orang asing yang datang setiap tahunnya di Kota Semarang pada tabel 1 merupakan data jumlah WNA yang berasal dari benua Afrika.

Tabel 1.Jumlah WNA Berdasarkan Benua Periode Januari 2013 s/d 28 April 2015

\begin{tabular}{lll}
\hline No & \multicolumn{1}{c}{ Benua } & \multicolumn{1}{c}{ Jumlah } \\
\hline 1 & Afrika & 148 \\
2 & Amerika & 1703 \\
3 & Asia & 9008 \\
4 & Australia & 340 \\
5 & Eropa & 1849 \\
\hline Total & & 13048 \\
\hline
\end{tabular}

Sumber : Arsip Informasi Keimigrasian Kantor Imigrasi Kelas I Semarang 2015 
Tabel 1 menggambarkan jumlah terbanyak WNA periode Januari 2013 sampai dengan 28 April 2015 yaitu berasal dari benua Asia sebanyak 9008 orang. Jumlah WNA di Asia lebih banyak dari benua-benua lainnya karena posisi negara-negara tersebut dekat dengan letak Indonesia yang berada di Asia Tenggara.

Benua Eropa memiliki jumlah WNA terbanyak kedua setelah benua Asia. Berdasarkan kebangsaan di benua Eropa, jumlah WNA terbanyak di kota Semarang yang berasal dari benua Eropa adalah negeri Kincir atau Belanda sebanyak 735 orang. Jumlah keseluruhan WNA yang berasal dari benua Eropa adalah 1849 orang.

Menurut Ryan Aditya, Kepala Sub Seksi Pengawasan di Kantor Imigrasi Kelas I Semarang mengatakan bahwa :

"Tidak ada batasan dan tidak ada larangan bagi orang asing datang ke Indonesia khususnya Semarang, selagi mereka tidak masuk dalam daftar cekal. Rata-rata orang asing yang berasal dari benua Eropa datang ke Semarang untuk urusan bisnis" (Wawancara, 14 April 2015).

Sejalan dengan pernyataan Ryan Aditya yang mengemukakan alasan orang asing khususnya Eropa berdatangan ke Indonesia adalah untuk keperluan bisnis, Supramono menjelaskan bahwa selama berada di Indonesia orang asing dapat melakukan kegiatan bisnis yang dipandang dapat menguntungkan dirinya. Peraturan perundang-undangan di Indonesia tidak menutup kemungkinan orang asing untuk berbisnis. Untuk perusahaan yang berbadan hukum asing tidak banyak yang memiliki kesempatan untuk berbisnis di Indonesia, keadaan ini diciptakan karena negara ingin melindungi perusahaan nasional. Meskipun demikian terdapat bidang-bidang tertentu yang terbuka untuk dimasuki perusahaan asing melakukan kegiatan bisnis. Bidang-bidang tersebut adalah bidang pertambangan minyak dan gas bumi, bidang angkutan laut dan angkatan udara khususnya untuk angkutan luar negeri. Selain itu juga di bidang perbankan, perusahaan asing hanya dapat mendirikan cabangnya di Indonesia (Supramono, 2012:3).
Penjelasan Supramono (2012) sesuai dengan keadaan di Indonesia khususnya Semarang. Saat ini banyak perusahaan asing yang mendirikan perusahaannya di Indonesia, seperti perusahaan multinasional Unilever yang didirikan tahun 1930 yang berkantor pusat di Rotterdam, Belanda. Perusahaan ini memproduksi barang kebutuhan keluarga di seluruh dunia seperti makanan, minuman, dan kebutuhan lainnya. Unilever Indonesia didirikan 5 Desember 1933 sebagai Zeepfabrieken N.V. Lever. Pada 30 Juni 1997, nama perusahaan diubah menjadi PT Unilever Indonesia Tbk (Unilever, 2015).

\section{b. Jenis - Jenis Perizinan Orang Asing}

Pada dasarnya orang asing yang berada di wilayah Indonesia wajib memiliki izin tinggal sesuai dengan visa yang dimilikinya (Undang-Undang Nomor 6 Tahun 2011 Pasal 48). Namun ketentuan tersebut tidak diberlakukan terhadap orang asing yang berada di wilayah Indonesia apabila menjadi korban tindak pidana perdagangan orang.

Jenis perizinan disesuaikan dengan kebutuhan orang asing yang datang ke wilayah Indonesia. Pasal 48 ayat 3 Undang-Undang Nomor 6 Tahun 2011 tentang Keimigrasian menjelaskan jenis-jenis perizinan di Indonesia, diantaranya sebagai berikut :

1. Izin Tinggal diplomatik.

2. Izin Tinggal dinas.

3. Izin Tinggal Kunjungan (ITK)

4. Izin Tinggal Terbatas (ITAS)

5. Izin Tinggal Tetap (ITAP)

Di kota Semarang orang asing yang memiliki izin tinggal umumnya hanya memiliki izin tinggal kunjungan (ITK), izin tinggal terbatas (ITAS), dan izin tinggal tetap (ITAP).

Tabel 2 Jumlah Perbandingan Volume WNA antar Jenis Perizinan Periode 2013-2015

\begin{tabular}{lll}
\hline No. & \multicolumn{1}{c}{ Jenis Perizinan } & Jumlah \\
\hline 1 & Izin Tinggal Tetap (ITAP) & 103 \\
2 & Izin Tinggal Terbatas (ITAS) & 6685 \\
3 & Izin Tinggal Kunjungan (ITK) & 6260 \\
\hline Total & & 13048 \\
\hline
\end{tabular}

Sumber : Hasil Penelitian dari Peneliti 
Warga negara asing (WNA) yang memiliki izin tinggal tetap di Semarang memiliki jumlah paling rendah diantara izin tinggal terbatas (ITAS) dan izin tinggal kunjungan (ITK), karena syarat memiliki izin tinggal tetap tidak mudah. Warga negara asing (WNA) memiliki jangka waktu 5 (lima) tahun sejak permintaan izin tinggal tetap diberikan.

Pasal 1 Undang-Undang Nomor 6 Tahun 2011 menyebutkan bahwa izin tinggal tetap adalah izin yang diberikan kepada orang asing tertentu untuk bertempat tinggal dan menetap di wilayah Indonesia sebagai penduduk Indonesia. Izin tinggal tetap diberikan kepada pemohon setelah menetap selama 3 (tiga) tahun berturut-turut di Indonesia. Untuk mendapatkan izin tinggal tetap pemohon telah mencapai usia perkawinannya minimal 2 (dua) tahun dan menandatangani Pernyataan Integrasi kepada Pemerintah Republik Indonesia (Pasal 54 ayat 1).

Izin tinggal yang telah diberikan kepada orang asing dapat dialih statuskan. Izin tinggal yang dapat dialih statuskan adalah izin tinggal kunjungan menjadi izin tinggal terbatas dan izin tinggal terbatas menjadi izin tinggal tetap (Pasal 56 UU Nomor 6 Tahun 2011).

Jenis perizinan lainnya yaitu izin tinggal terbatas. Pemegang izin tinggal terbatas dan pemegang izin tinggal tetap dapat melakukan pekerjaan atau usaha untuk memenuhi kebutuhan hidup atau keluarganya. Izin tinggal kunjungan dan izin tinggal terbatas dapat juga dialih statuskan menjadi izin tinggal dinas (Pasal 61 UU Nomor 6 Tahun 2011).

Pemegang izin tinggal terbatas dapat dialih statuskan izinnya menjadi izin tinggal tetap. Pengalihan status diberikan atas permintaan orang asing yang bersangkutan, dengan syarat telah berada di wilayah Negara Republik Indonesia sekurang-kurangnya lima tahun berturut-turut terhitung sejak tanggal diberikannya izin tinggal terbatas (Pasal 56 UU Nomor 6 Tahun 2011).

Izin tinggal kunjungan diberikan kepada orang asing yang masuk wilayah Indonesia dengan visa kunjungan. Izin kunjungan untuk keperluan wisata, jangka waktu diberikan selama 60 (enam puluh) hari dan tidak dapat diperpanjang. Izin kunjungan dapat dialihkan statusnya menjadi izin tinggal terbatas.
Pengalihan status diberikan atas dasar permintaan orang asing yang bersangkutan dan sponsornya, dengan syarat telah berada di wilayah negara Republik Indonesia sekurangkurangnya empat bulan berturut-turut terhitung sejak tanggal diberikannya izin masuk di wilayah negara Republik Indonesia (Pasal 48 PP 32 Tahun 1994).

Berdasarkan jenis-jenis perizinan tersebut pemerintah Indonesia mengeluarkan peraturan pelayanan keimigrasian bagi orang asing yang harus dikeluarkan untuk mendapatkan izin tinggal (tetap, terbatas, dan kunjungan) di Indonesia. Pengaturan tersebut adalah Peraturan Pemerintah Nomor 45 Tahun 2014 Tentang Jenis dan Tarif Atas Jenis Penerimaan Negara Bukan Pajak yang Berlaku pada Kementerian Hukum dan Hak Asasi Manusia.

Tabel 3 .Biaya Pelayanan Keimigrasian

\begin{tabular}{|c|c|c|}
\hline No. & Jenis Perizinan & Biaya \\
\hline 1 & Izin Tinggal Kunjungan & 300.000 \\
\hline 2 & $\begin{array}{l}\text { Izin Tinggal Terbatas } \\
\text { (Baru/Perpanjangan) }\end{array}$ & \\
\hline 3 & Saat kedatangan & 450.000 \\
\hline 4 & Berlaku 6 bulan & 450.000 \\
\hline 5 & Berlaku 1 tahun & \\
\hline 6 & Berlaku 2 tahun & 1.400 .000 \\
\hline 7 & Exit Re-Entry Permit & 200.000 \\
\hline 8 & $\begin{array}{l}\text { Multiple Exit Re-Entry } \\
\text { Permit } 6 \text { bulan }\end{array}$ & 600.000 \\
\hline 9 & $\begin{array}{l}\text { Multiple Exit Re-Entry } \\
\text { Permit } 1 \text { tahun }\end{array}$ & 1.000 .000 \\
\hline 10 & $\begin{array}{l}\text { Multiple Exit Re-Entry } \\
\text { Permit } 2 \text { tahun }\end{array}$ & 1.750 .000 \\
\hline 11 & Izin Tinggal Tetap & 3.500 .000 \\
\hline 12 & $\begin{array}{l}\text { Biaya Beban (Orang as- } \\
\text { ing berada di Indonesia } \\
\text { kurang dari } 60 \text { hari) }\end{array}$ & 300.000 \\
\hline
\end{tabular}

Sumber : PP Nomor 45 Tahun 2014

Berdasarkan rincian biaya di atas, jenis perizinan dengan biaya tertinggi adalah izin tinggal tetap yaitu sebesar Rp 3.500.000,00. Ryan Aditya Kepala Subseksi Pengawasan mengatakan bahwa :

"Biaya untuk izin tinggal tetap paling tinggi diantara biaya izin tinggal lainnya 
karena izin tinggal tetap berlaku untuk 5 tahun" (Wawancara, 14 April 2015).

Izin tinggal tetap diberikan kepada orang asing yang telah menetap di wilayah Indonesia secara berturut-turut untuk jangka waktu tertentu dan memenuhi persyaratanpersyaratan keimigrasian serta syarat-syarat lain (Sjahriful, 1993:83).

Sejalan dengan pernyataan Ryan Aditya, izin tinggal tetap dapat diperpanjang untuk waktu tidak terbatas dengan membayar biaya sebesar Rp 10.000.000,00 dan wajib melapor setiap 5 (lima) tahun sekali tanpa dikenai biaya. Pemohon juga mengisi Pernyataan Integritas Republik Indonesia sebagai syarat mengajukan izin tinggal tetap.

\section{c. Pelanggaran Izin Tinggal Warga Negara Asing di Kota Semarang}

Warga negara asing yang berkunjung ke Indonesia berdasarkan jenis-jenis perizinan yang ada, walaupun telah memiliki izin untuk memasuki wilayah Indonesia masih ada pelanggaran yang dilakukan orang asing. Yu,Pei-Ya wisatawan asal Taiwan yang berkunjung ke Semarang mengatakan bahwa :

"I used travel visa when I visit Semarang" (saya menggunakan visa perjalanan ketika saya mengunjungi Semarang) (Wawancara, 27 April 2015).

Visa perjalanan (travel visa) adalah salah satu jenis visa di Taiwan dari berbagai macam visa seperti working holiday for tourist (Liburan untuk turis), for business (bisnis), diplomacy (diplomatik), emigration (emigrasi), working (bekerja), and for study (dan untuk belajar) (Wawancara, 27 April 2015).

Yu,Pei-Ya menggunakan visa perjalanan (travel visa) dari negaranya karena visa tersebut mudah didapat. Wisatawan asal Taiwan ini mengungkapkan :

"Because it's easier to apply, need only simple documents, and I can get it in a very short time" (Karena visa tersebut lebih mudah didapatkan, hanya butuh dokumen-dokumen sederhana, dan saya bisa mendapatkan visa tersebut dalam waktu singkat) (Wawancara, 27 April 2015).

Visa perjalanan (travel visa) yang digu- nakan Yu,Pei-Ya hanya berlaku di Indonesia khususnya Semarang selama 30 hari. Sedangkan Yu,Pei-Ya tinggal sementara di Semarang selama 45 hari. Yu,Pei-Ya mengatakan

"I extended my visa too late. At first I thought it would only took no more than a week, so I extended my visa one week before it expired, and it took more than three weeks. So I became an overstay person" (Saya memperpanjang visa terlambat. Pada mulanya saya pikir hanya butuh tidak lebih dari seminggu. Jadi saya memperpanjang visa saya seminggu sebelum masa berlakunya habis, dan ternyata membutuhkan waktu lebih dari 3 (tiga) minggu. Jadi saya pun melanggar izin tinggal) (Wawancara, 27 April 2015).

Jenis perizinan yang digunakan Yu,PeiYa di Indonesia adalah izin tinggal kunjungan. Izin Kunjungan diberikan kepada orang asing untuk berkunjung ke wilayah Negara Republik Indonesia untuk jangka waktu 60 (enam puluh) hari terhitung sejak tanggal diberikannya Izin Masuk di wilayah Negara Republik Indonesia (Pasal 35 PP No. 32 Tahun 1994).

Pernyataan Yu,Pei-Ya mencerminkan kelalaian dirinya. la berpikir bahwa perpanjangan visa di Semarang mudah seperti di Taiwan, dan Yu,Pei-Ya tidak memberi kabar kepada penjamin/sponsornya lebih awal terkait dengan permasalahannya. Akibatnya Yu,Pei-Ya melanggar izin tinggal karena melebihi batas waktu tinggal di Semarang (overstay).

Sesuai dengan Pasal 75 ayat 1 tentang tindakan administratif yang berbunyi pejabat imigrasi berwenang melakukan tindakan administratif keimigrasian terhadap orang asing yang berada di Wilayah Indonesia yang melakukan kegiatan berbahaya dan patut diduga membahayakan keamanan dan ketertiban umum atau tidak menghormati atau tidak menaati peraturan perundang-undangan. Wisatawan asal Taiwan tersebut tidak menaati peraturan perundang-undangan, sehingga Yu,Pei-Ya dikenakan sanksi berupa tindakan administratif yaitu pengenaan biaya beban (Pasal 75 ayat (2) huruf e) karena melewati masa berlaku izin tinggal selama 1 (satu) minggu. Namun Yu,Pei-Ya hanya mendapat 
surat peringatan dari Kantor Imigrasi Kelas I Semarang karena Yu,Pei-Ya memiliki penjamin dari sebuah organisasi di Universitas Diponegoro yaitu AIESEC dan mendapat surat rekomendasi dari Rektor UNDIP Semarang, sehingga Yu,Pei-Ya tidak dikenakan biaya beban.

Orang asing lainnya yang melanggar izin tinggal di Semarang yaitu Ferry Jie, kebangsaan Australia dengan nomor paspor M7003426. Tujuan Ferry Jie di Indonesia adalah untuk melakukan penelitian di Semarang, Jawa Tengah dalam bidang Ekonomi dan Manajemen. Penelitian tersebut diperkirakan akan memerlukan waktu 4 (empat) bulan mulai Desember 2014. Ferry Jie datang ke Kantor Imigrasi Kelas I Semarang untuk mengajukan permohonan perpanjangan izin tinggal, namun setelah dilakukan pemeriksaan dokumen oleh petugas loket ternyata visa tinggal terbatasnya sudah melebihi waktu (overstay) selama 26 hari. Visa tinggal terbatas Ferry Jie habis pada 21 November 2014.

Ferry Jie melapor kejadian tersebut kepada Seksi Pengawasan dan Penindakan Keimigrasian. Saat diperiksa yang bersangkutan mengatakan bahwa masa izin tinggal yang tertulis di visa tinggal terbatas adalah 4 (empat) bulan dan baru menyadari bahwa Ferry Jie seharusnya mengajukan permohonan perpanjangan izin tinggal 1 bulan setelah mendarat di Indonesia. Ferry Jie menambahkan bahwa dirinya tidak mengetahui hal tersebut, dan berkas permohonannya masih menunggu Surat Rekomendasi dari Kemenristek RI. Ferry Jie tidak mengetahui prosedur permohonan izin tinggal terbatas secara lengkap dan jelas karena kurangnya informasi yang didapat dari pihak-pihak terkait (Arsip Kantor Imigrasi Kelas I Semarang, 2014).

Sesuai dengan Pasal 75 ayat 1 tentang tindakan administratif yang berbunyi pejabat imigrasi berwenang melakukan tindakan administratif keimigrasian terhadap orang asing yang berada di Wilayah Indonesia yang melakukan kegiatan berbahaya dan patut diduga membahayakan keamanan dan ketertiban umum atau tidak menghormati atau tidak menaati peraturan perundang-undangan.

Berdasarkan keterangan di atas, Ferry
Jie tidak menghormati atau tidak menaati peraturan dalam mengurusi visa tinggal terbatas yang dimilikinya. Kurangnya antusias Ferry Jie dalam mengurusi prosedur permohonan izin tinggal menyebabkan dirinya melanggar keimigrasian (overstay).

Sesuai dengan Pasal 75 ayat 2 Ferry Jie dikenakan tindakan administratif berupa pengenaan biaya beban Rp 7.800.00,00 karena melewati masa berlaku izin tinggal selama 26 (dua puluh enam) hari.

Okky Setyawan sebagai Kepala Subseksi Penindakan menjelaskan beberapa penyebab orang asing mengalami pelanggaran keimigrasian (overstay) yaitu :

"Pertama, ketidaktahuan orang asing terhadap peraturan di Indonesia, karena sebagian besar orang asing menyerahkan urusan izin tinggal kepada penjamin/sponsornya. Kedua, ketidak pedulian orang asing, mereka menganggap jika melakukan pelanggaran keimigrasian (overstay) mereka hanya membayar sejumlah biaya beban dan selesailah permasalahan (overstay) tersebut. Ketiga, terpaksa karena sakit dalam jangka waktu yang panjang sehingga menyulitkan mereka untuk memperpanjang masa izin tinggal" (Wawancara, 31 Maret 2015).

Agar Indonesia tetap aman dan tenteram diperlukan pengawasan orang asing di wilayah Indonesia, berupa pengawasan terhadap orang asing yang masuk, keberadaan, kegiatan dan keluar dari wilayah Indonesia, antara lain dapat menimbulkan 2 (dua) kemungkinan yakni: Pertama, Orang asing mantaati peraturan yang berlaku dan tidak melakukan kegiatan yang berbahaya bagi keamanan dan ketertiban umum, hal ini tidak menimbulkan masalah Keimigrasian maupun Kenegaraan. Kedua Orang asing tidak mentaati peraturan perundang-undangan yang berlaku di Indonesia, hal ini menimbulkan masalah dan dapat dikenakan tindakan hukum berupa :

1. Tindakan Hukum Pidana berupa penyidikan Keimigrasian yang merupakan bagian daripada rangkaian Integrated Criminal Justice sistem, sistem peradilan pidana (penyidikan, penuntutan, 
peradilan) contohnya penyelundupan narkoba, penyelundupan senjata api dan barang-barang terlarang lainnya; dan/ atau

2. Tindakan hukum administratif negara berupa tindakan keimigrasian adalah tindakan administratif dalam bidang keimigrasian di luar proses peradilan. Termasuk bagian daripada tindakan keimigrasian ini adalah diantaranya deportasi terhadap orang asing untuk keluar dari wilayah yurisdiksi negara kesatuan Republik Indonesia contohnya penyalahgunaan ijin tinggal keimigrasian, overstay, imigran gelap dan lain sebagainya (Ukun, 2004).

\section{a. Penegakan Hukum Terhadap Warga Negara Asing (WNA) yang Masa Berlaku Izin Tinggalnya Telah Habis (Overstay)}

Disini peneliti ingin membahas penegakan hukum terhadap warga negara asing (WNA) yang melanggar izin tinggal di Indonesia khususnya Semarang. Hukum keimigrasian merupakan bagian dari sistem hukum yang berlaku di Indonesia, bahkan merupakan subsistem dari hukum administrasi negara. Fungsi keimigrasian merupakan fungsi penyelenggaraan administrasi negara atau penyelenggaraan administrasi pemerintahan, oleh karena itu sebagai bagian dari penyelenggaraan kekuasaan eksekutif, yaitu fungsi administrasi negara dan pemerintahan, maka hukum keimigrasian dapat dikatakan bagian dari bidang hukum administrasi negara.

Agar orang asing berlaku tertib selama berada di Indonesia, dilakukan pengawasan oleh Pemerintah melalui Dirjen Imigrasi Kementerian Hukum dan HAM. Secara garis besarnya pengawasan terhadap orang asing di Indonesia meliputi dua hal yaitu masuk dan keluarnya orang asing ke dan dari wilayah Indonesia, dan keberadaan serta kegiatan orang asing di wilayah Indonesia.

Pengawasan terhadap orang asing dilaksanakan Pemerintah dalam bentuk dan cara sebagai berikut :

1. Pengumpulan dan pengolahan data orang asing yang masuk atau keluar wilayah Indonesia;

2. Pendaftaran orang asing yang berada di wilayah Indonesia;

3. Pemantauan, pengumpulan, dan pengolahan bahan keterangan dan informasi mengenai kegiatan orang asing;

4. Penyusunan daftar nama-nama orang asing yang tidak dikehendaki masuk atau keluar wilayah Indonesia; dan

5. Kegiatan lainnya (Supramono, 2012:1314).

Penegakan hukum di Kantor Imigrasi dilaksanakan oleh 2 (dua) seksi, yaitu seksi Pengawasan dan Penindakan. Pengawasan orang asing dilakukan untuk mengawasi kegiatan orang asing yang tinggal di wilayah Indonesia, baik kunjungan, tinggal sementara maupun menetap. Pasal 66 ayat (2) UndangUndang Nomor 6 Tahun 2011, Pengawasan Keimigrasian meliputi :

a. Pengawasan terhadap warga negara Indonesia yang memohon dokumen perjalanan, keluar atau masuk Wilayah Indonesia, dan yang berada di luar Wilayah Indonesia; dan

b. Pengawasan terhadap lalu lintas orang asing yang masuk atau keluar Wilayah Indonesia serta pengawasan terhadap keberadaan dan kegiatan orang asing di Wilayah Indonesia.

Pengawasan pertama dilakukan saat orang asing mengajukan permohonan pembuatan visa di Kedutaan Republik Indonesia di luar negeri. Setelah dikabulkan permohonannya, pengawasan selanjutnya yaitu memeriksa kelengkapan administrasi seperti paspor dan visa di Tempat Pemeriksaan Imigrasi (TPI) yang ada di Bandar udara atau pelabuhan.

Orang asing yang berada di Indonesia kegiatan dan keberadaannya diawasi oleh Pejabat Imigrasi. Setiap orang asing berada di wilayah Indonesia wajib memberikan keterangan yang diperlukan mengenai identitas diri dan atau keluarganya, perubahan status sipil kewarganegaraannya serta perubahan alamnya. Status sipil yang dimaksud adalah perubahan yang menyangkut perkawinan, perceraian, kematian, kelahiran anak, pindah pekerjaan dan berhenti dari pekerjaan.

Berbicara mengenai pengawasan ter- 
hadap orang asing, Ryan Aditya Kepala Subseksi Pengawasan menjelaskan bahwa :

"Orang asing yang akan keluar dari wilayah Indonesia diperiksa kembali kelengkapan administrasinya. Apabila terdapat laporan bahwa orang asing tersebut melakukan suatu tindak pidana atau pelanggaran keimigrasian, maka orang asing tersebut tidak diperbolehkan keluar dari wilayah Indonesia dan ditempatkan di rumah detensi imigrasi" (Wawancara, 14 April 2015).

Jika benar bahwa orang asing melakukan pelanggaran, maka seksi penindakan Kantor Imigrasi berperan sesuai Pasal 74 Undang-Undang Nomor 6 Tahun 2011 mengenai Intelijen Keimigrasian :

Pejabat Imigrasi melakukan fungsi Intelijen Keimigrasian.

1. Dalam rangka melaksanakan fungsi Intelijen Keimigrasian, Pejabat Imigrasi melakukan penyelidikan Keimigrasian dan pengamanan Keimigrasian serta berwenang :

a. Mendapatkan keterangan dari masyarakat atau instansi pemerintah;

b. Mendatangi tempat atau bangunan yang diduga dapat ditemukan bahan keterangan mengenai keberadaan dan kegiatan orang asing;

c. Melakukan operasi intelijen keimigrasian; atau

d. Melakukan pengamanan terhadap data dan informasi keimigrasian serta pengamanan pelaksanaan tugas keimigrasian.

1) Pelaksanaan Penegakan Hukum Terhadap Warga Negara Asing (WNA) di Kota Semarang

Pengawasan dan penindakan keimigrasian terhadap orang asing merupakan upaya pemerintah yang sekaligus merupakan ruang lingkup keimigrasian untuk menciptakan keamanan dan ketertiban umum. Secara garis besar fungsi pengawasan dan penindakan orang asing dirumuskan dalam tri fungsi imi- grasi, yaitu sebagai aparatur pelayanan masyarakat dan pengamanan negara, penegakan hukum keimigrasian, dan fasilitator ekonomi nasional.

Menurut Ryan Aditya sebagai Kepala Subseksi Pengawasan mengatakan bahwa :

"Pengawasan yang dilakukan pertama kali saat masuk dan keluar wilayah Indonesia diantaranya permohonan visa orang asing diawasi tujuannya, lalu dikirim ke Kedutaan Besar Negara yang bersangkutan lalu diambil. Di Bandar udara dilakukan pemeriksaan ulang kelengkapan administrasi di Tempat Pemeriksaan Imigrasi (TPI) hingga sampai di suatu wilayah. Pemeriksaan lebih mendalam pada administrasi, namun secara kesisteman langsung ke lapangan" (Wawancara, 14 April 2015).

Sejalan dengan pernyataan Ryan Aditya Kantor Imigrasi Kelas I Semarang tindakan pengawasan kelengkapan administrasi orang asing yang akan masuk ke wilayah Indonesia telah sesuai dalam Pasal 68 Undang-Undang Nomor 6 Tahun 2011. Pengawasan Keimigrasian terhadap orang asing dilakukan dengan cara pengumpulan, pengolahan, serta penyajian data dan informasi, penyusunan daftar nama orang asing yang dikenai Penangkalan atau Pencegahan, pengawasan terhadap keberadaan dan kegiatan orang asing di Wilayah Indonesia, pengambilan foto dan sidik jari, dan kegiatan lain yang dapat dipertanggungjawabkan secara hukum (Pasal 68 Undang-Undang Nomor 6 Tahun 2011). Pengawasan dilakukan untuk memastikan bahwa nama orang asing yang ada di wilayah Indonesia tidak ada dalam daftar pencegahan dan penangkalan.

Apabila dalam pengawasan ditemukan pelanggaran keimigrasian seperti penyalahgunaan izin tinggal, masa izin tinggal telah habis (overstay), dan tidak memiliki izin tinggal (illegal stay) maka dilakukan tindakan keimigrasian diantaranya tindakan administratif dan pro justicia.

Menurut Okky Setyawan sebagai Kepala Subseksi Penindakan mengatakan bahwa :

"Pelanggaran masa izin tinggal yang telah habis (overstay) ditindak secara admi- 
nistratif. Selain itu pelanggaran lain yang dapat ditindak secara administratif yaitu jika di Indonesia terdapat propaganda seperti ISIS (Islamic State Iran Syria). Tindakan administratif seperti deportasi diberikan kepada propaganda karena lebih cepat dari tindakan pro justicia, apabila keberadaan propaganda lebih lama di Indonesia akan membahayakan keamanan negara" (Wawancara, Okky Setyawan:31 Maret 2015).

Sejalan dengan pernyataan Okky Setyawan, tindakan administratif yang diberikan kepada orang asing yang melanggar izin tinggal telah sesuai dengan Pasal 78 Undang-Undang Nomor 6 Tahun 2011 yang berbunyi :

1. Orang Asing pemegang Izin Tinggal yang telah berakhir masa berlakunya dan masih berada dalam Wilayah Indonesia kurang dari 60 (enam puluh) hari dari batas waktu Izin Tinggal dikenai biaya beban sesuai dengan ketentuan peraturan perundangundangan.

2. Orang Asing yang tidak membayar biaya beban sebagaimana dimaksud pada ayat (1) dikenai Tindakan Administratif Keimigrasian berupa Deportasi dan Penangkalan.

3. Orang Asing pemegang Izin Tinggal yang telah berakhir masa berlakunya dan masih berada dalam Wilayah Indonesia lebih dari 60 (enam puluh) hari dari batas waktu Izin Tinggal dikenai Tindakan Administratif Keimigrasian berupa Deportasi dan Penangkalan.

Dengan demikian penegakan hukum terhadap warga negara asing (WNA) di kota Semarang telah sesuai dengan Undang-undang Nomor 6 Tahun 2011 Tentang Keimigrasian.

2) Pemberian Tindakan Administratif Terhadap Warga Negara Asing (WNA) yang Melanggar Izin Tinggal (Overstay)

Orang asing yang berada di wilayah Indonesia melakukan kegiatan berbahaya atau patut diduga akan berbahaya bagi keamanan dan ketertiban umum, atau tidak menghormati atau mentaati peraturan perundang-undangan yang berlaku, Pemerintah melakukan tindakan keimigrasian yang berupa :

1. Pembatasan, perubahan atau pembatalan izin keberadaan;

2. Larangan untuk berada di suatu atau beberapa tempat tertentu di wilayah Indonesia;

3. Keharusan untuk bertempat tinggal di suatu tempat tertentu di wilayah Indonesia;

4. Pengusiran atau deportasi dari wilayah Indonesia atau penolakan masuk ke wilayah Indonesia (Supramono, 2012:13-14).

Tindakan administratif dibagi menjadi beberapa jenis, diantaranya pencantuman dalam daftar pencegahan atau penangkalan, pembatasan, perubahan, atau pembatalan izin tinggal, larangan untuk berada di satu atau beberapa tempat tertentu di wilayah Indonesia, keharusan untuk bertempat tinggal di suatu tempat tertentu di wilayah Indonesia, pengenaan biaya beban, dan deportasi dari wilayah Indonesia (Pasal 75 Ayat 2 Undang-Undang Nomor 6 Tahun 2011).

Berdasarkan penjelasan tersebut pada grafik 1 adalah data jumlah orang asing yang melanggar izin tinggal di Semarang berdasarkan Laporan Penyidikan dan Penindakan Imigrasi (Nyidakim) 2013 (Kantor Imigrasi Kelas I Semarang, 2015).

Berdasarkan grafik 1 dapat dilihat bahwa pada tahun 2013 orang asing setiap bulannya membayar biaya beban karena melanggar keimigrasian (overstay). Pada Januari sebanyak 9 orang, Februari sebanyak 9 orang, Maret sebanyak 5 orang, April sebanyak 14 orang, Mei sebanyak 3 orang, Juni sebanyak 5 orang, Juli sebanyak 10 orang, Agustus sebanyak 5 orang, September sebanyak 12 orang, Oktober sebanyak 1 orang, November sebanyak 58 orang, dan Desember sebanyak 7 orang sehingga jumlah keseluruhan orang asing yang membayar biaya beban sebanyak 138 orang. Deportasi orang asing diberikan kepada orang asing pada bulan Januari sebanyak 4 orang, Juli sebanyak 1 orang dan Desember sebanyak 1 orang. 


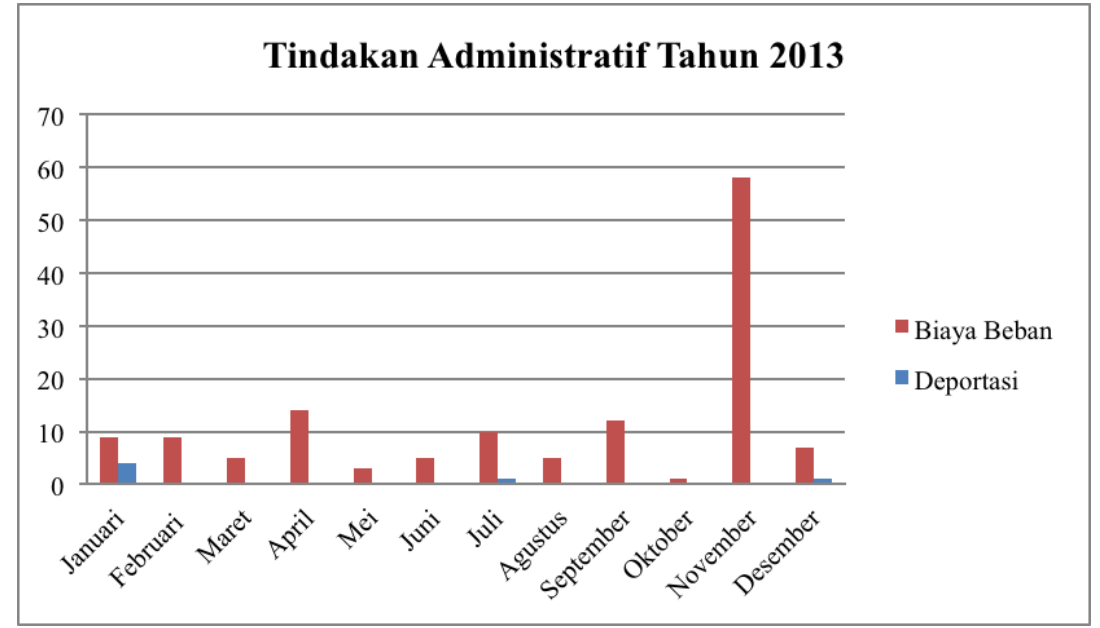

Grafik 1. Tindakan Administratif Tahun 2013

Sumber : Arsip Subseksi Penindakan Imigrasi Kantor Imigrasi Kelas I Semarang

Jumlah orang asing yang melanggar izin tinggal (overstay) di Semarang pada tahun 2013 dengan sanksi membayar biaya beban adalah sebanyak 133 orang dan jumlah orang asing yang dideportasi sebanyak 6 orang.

Pengenaan biaya beban disesuaikan dengan pelanggaran yang dilakukan. Pasal 78 ayat 1 menyebutkan orang asing pemegang izin tinggal yang telah berakhir masa berlakunya dan masih berada dalam Wilayah Indonesia kurang dari 60 (enam puluh) hari dari batas waktu izin tinggal dikenai biaya beban sesuai dengan ketentuan peraturan perundang-undangan.
Tindakan administratif berupa deportasi dilakukan sesuai Pasal 78 ayat 2 dan 3 yaitu apabila orang asing tidak dapat membayar biaya beban dan orang asing pemegang izin tinggal yang telah berakhir masa berlakunya dan masih berada dalam Wilayah Indonesia lebih dari 60 (enam puluh) hari dari batas waktu Izin Tinggal dikenai tindakan administratif keimigrasian berupa deportasi dan penangkalan.

Grafik 2 adalah jumlah orang asing yang melanggar izin tinggal di Semarang berdasarkan Laporan Penyidikan dan Penindakan Imigrasi (Nyidakim) 2014 (Kantor Imigra-

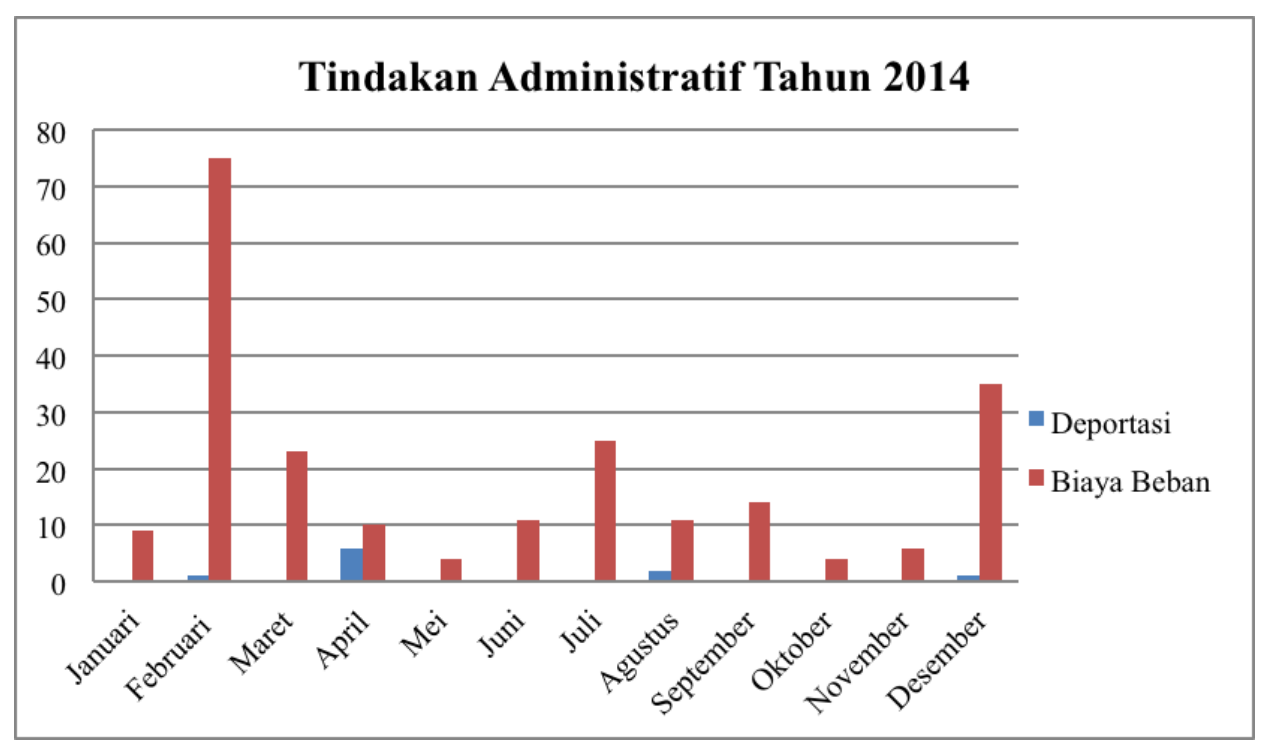

Grafik 2. Tindakan Administratif Tahun 2014

Sumber : Arsip Subseksi Penindakan Imigrasi Kantor Imigrasi Kelas I Semarang 


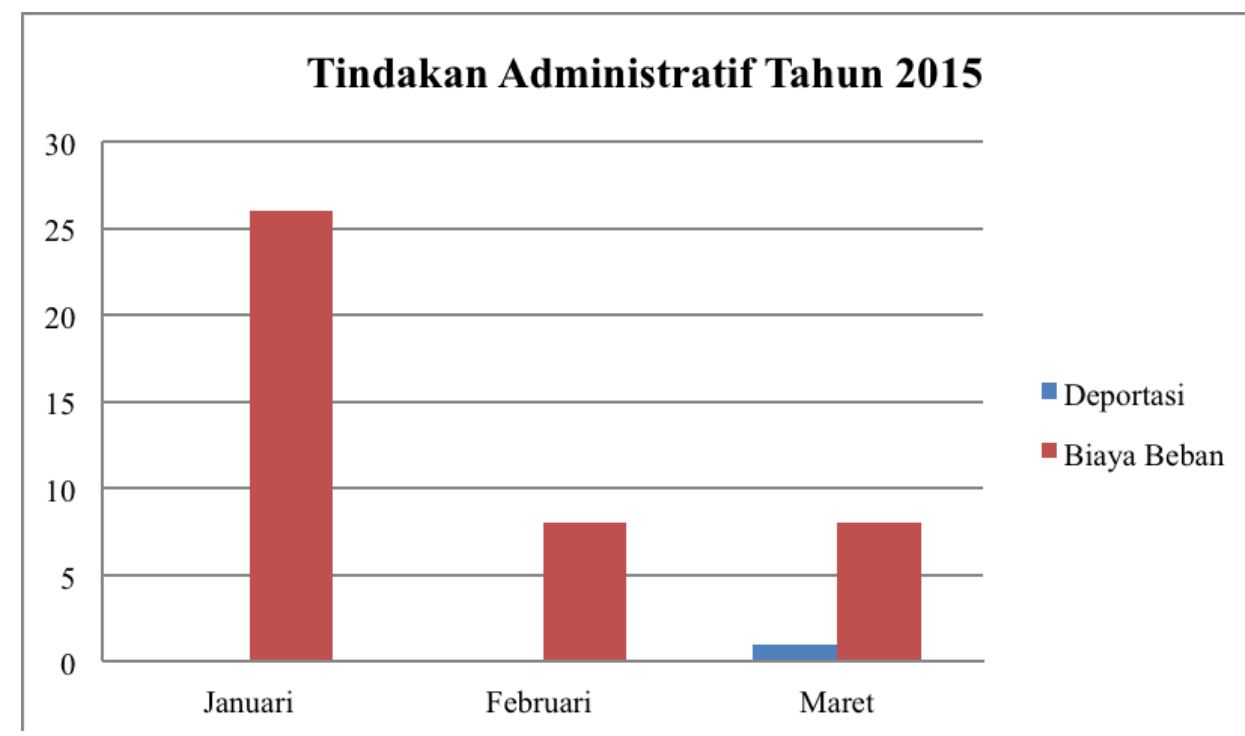

Grafik 3. Tindakan Administratif Tahun 2015

Sumber : Arsip Subseksi Penindakan Imigrasi Kantor Imigrasi Kelas I Semarang

si Kelas I Semarang, 2015).

Sesuai grafik 2 dapat dilihat bahwa tahun 2014 jumlah orang asing yang membayar biaya beban pada bulan Januari sebanyak 9 orang, Februari sebanyak 75 orang, Maret sebanyak 23 orang, April sebanyak 10 orang, Mei sebanyak 4 orang, Juni sebanyak 11 orang, Juli sebanyak 25 orang, Agustus sebanyak 11 orang, September sebanyak 14 orang, Oktober sebanyak 4 orang, November sebanyak 6 orang, dan Desember sebanyak 35 orang. Deportasi diberikan kepada orang asing pada tahun 2014 yaitu pada Februari sebanyak 1 orang, April sebanyak 6 orang, Agustus sebanyak 2 orang, dan Desember sebanyak 1 orang. Jumlah keseluruhan sebanyak 227 orang dan sebanyak 10 orang asing dideportasi dari wilayah Indonesia.

Grafik 3 adalah jumlah orang asing yang melanggar izin tinggal di Semarang berdasarkan Laporan Penyidikan dan Penindakan Imigrasi (Nyidakim) Januari sampai dengan Maret 2015 (Kantor Imigrasi Kelas I Semarang, 2015).

Berdasarkan grafik 3 pada Januari sebanyak 26 orang, Februari sebanyak 8 orang dan Maret sebanyak 8 orang. Deportasi diberikan pada bulan Maret sebanyak 1 orang, sehingga jumlah keseluruhan orang aasing yang membayar denda sebanyak 42 orang dan 1 orang asing dideportasi.

Grafik tersebut menggambarkan fluktu- asi jumlah orang asing yang melanggar izin tinggal (overstay) selama 3 (tiga) tahun berturut-turut. Tidak setiap bulannya meningkat atau menurun, namun berubah-ubah.

Kasubsi Penindakan Kantor Imigrasi Kelas I Semarang Okky Setyawan mengatakan, jumlah orang asing yang melanggar izin tinggal (overstay) kemungkinan meningkat hingga akhir tahun 2015 (Wawancara,31 Maret 2015).

Berdasarkan grafik tersebut, jumlah orang asing yang melanggar izin tinggal (overstay) di Kota Semarang pada Januari 2013 sampai dengan Maret 2015 sebanyak 402 orang dikenakan sanksi administratif yaitu membayar biaya beban dan sebanyak 17 orang asing yang dideportasi.

\section{Tabel 4. Jumlah Denda Overstay}

\begin{tabular}{llc}
\hline No. & Periode & Jumlah (Rp) \\
\hline 1 & $\begin{array}{l}\text { Januari - } \\
\text { Desember 2013 }\end{array}$ & \pm 400.000 .000 \\
2 & $\begin{array}{l}\text { Januari - } \\
\text { Desember 2014 }\end{array}$ & 482.000 .000 \\
3 & $\begin{array}{l}\text { Januari - } \\
\text { 28 April 2015 }\end{array}$ & 130.500 .000 \\
\hline
\end{tabular}

Sumber : Seksi Informasi dan Komunikasi Keimigrasian, 2015

Jumlah denda overstay (PNBP) masuk ke kas negara dan digunakan sebagian untuk melakukan pembangunan negara, khusus- 
nya untuk pembangunan sarana dan prasarana pelayanan keimigrasian, pengawasan dan penegakan hukum yang menjadi fungsi Imigrasi Indonesia, fasilitas makan serta transportasi bagi Petugas Pemeriksa Keimigrasian, dan biaya pengawalan dari perwakilan Kantor Imigrasi terhadap Warga Negara Asing (WNA) yang dideportasi dari Indonesia.

\section{b. Faktor-Faktor yang Mempengaruhi Penegakan Hukum Terhadap Warga Negara Asing (WNA) yang Masa Berlaku Izin Tinggalnya Telah Habis (Overstay)}

\section{1) Faktor Pendukung}

Kantor Imigrasi Kelas I Semarang dalam menegakan hukum terhadap orang asing yang melanggar izin tinggal (overstay) diwujudkan dalam pengawasan dan penindakan keimigrasian.

Pertama, dalam hal pengawasan yang dilakukan oleh tim pengawas Kantor Imigrasi Kelas I Semarang bekerja sama dengan pejabat imigrasi di Bandar udara atau pelabuhan melakukan pemeriksaan ulang kelengkapan administrasi orang asing di Tempat Pemeriksaan Imigrasi (TPI) hingga sampai di suatu wilayah. Dalam hal menambah jumlah personil pengawasan, Kepala Kantor Imigrasi Kelas I Semarang membuat SK Tim Pengawasan Orang Asing yang mengambil sebanyak 2 (dua) orang dari tiap seksi yang ada di Kantor Imigrasi Kelas I Semarang.

Kedua, pelanggaran masa izin tinggal yang telah habis (overstay) ditindak secara administratif. Tindakan administrasi diberikan kepada pelanggar izin tinggal karena memuat hal tentang pengaturan, pelayanan, perijinan dari aspek-aspek keimigrasian yaitu mengenai masuk dan keluar wilayah Indonesia. Penindakan keimigrasian di Semarang bekerja sama dengan instansi terkait seperti Kepolisian Daerah Jawa Tengah, Polisi Resor Kota Besar Semarang beserta jajarannya selaku koordinator pengawasan sehingga penindakan berjalan dengan baik.

Tekait dengan penegakan hukum di Kantor Imigrasi Kelas I Semarang, Soerjono Soekanto (2014:8) mengemukakan teori faktor-faktor yang mempengaruhi penegakan hukum. Faktor-faktor tersebut yaitu :

1. Faktor hukumnya sendiri (UndangUndang).

2. Faktor penegak hukum, yakni pihakpihak yang membentuk maupun menerapkan hukum.

3. Faktor sarana atau fasilitas yang mendukung penegakan hukum.

4. Faktor masyarakat, yakni lingkungan dimana hukum tersebut berlaku atau diterapkan.

5. Faktor kebudayaan, yakni sebagai hasil karya, cipta dan rasa yang didasarkan pada karsa manusia di dalam pergaulan hidup (Soekanto, 2014).

Faktor pendukung lainnya mengenai penegakan hukum yaitu faktor hukumnya sendiri (Undang-Undang) bahwa berdasarkan pertimbangan keadaan dan kebutuhan saat ini maka dibentuk undang-undang baru tentang keimigrasian yaitu Undang-Undang Nomor 6 Tahun 2011 yang berpedoman pada Peraturan Pemerintah Nomor 13 Tahun 2013 Tentang Peraturan Pelaksanaan Undang-Undang Nomor 6 Tahun 2011 tentang Keimigrasian, Peraturan Pemerintah Nomor 38 Tahun 2005 Tentang Perubahan Kedua atas Peraturan Pemerintah Nomor 32 Tahun 1994 Tentang Visa, Izin Masuk, dan Izin Keimigrasian serta Peraturan Pemerintah Nomor 45 Tahun 2014 Tentang Jenis dan Tarif Atas Jenis Penerimaan Negara Bukan Pajak yang Berlaku pada Kementerian Hukum dan Hak Asasi Manusia. Dengan demikian diharapkan dan sudah sepatutnya Kantor Imigrasi Kelas I Semarang mampu menjalankan dan mewujudkan penegakan hukum keimigrasian. Hal ini dibuktikan Kantor Imigrasi Kelas I Semarang mampu menegakan hukum dalam bidang pengawasan orang asing di wilayah Jawa Tengah, memberikan tindakan administratif kepada orang asing yang melanggar izin tinggal (overstay) walaupun belum terlaksana secara optimal karena masih ada faktorfaktor yang menghambat dalam penegakan hukum.

Faktor berikutnya yaitu sarana atau fasilitas yang mendukung penegakan hukum, mencakup tenaga manusia yang berpendidikan dan terampil, organisasi yang baik, pera- 
latan yang memadai, keuangan yang cukup, dan seterusnya. Penegakan hukum di Kantor Imigrasi Kelas I Semarang berjalan dengan baik karena jumlah tim pengawasan telah ditambah dan rata-rata pendidikan para pejabat imigrasi di Kantor Imigrasi Kelas I Semarang minimal Strata-1. Dalam hal anggaran Kantor Imigrasi Kelas I Semarang tidak mengalami kekurangan anggaran.

Faktor selanjutnya yaitu masyarakat yakni lingkungan dimana hukum tersebut berlaku atau diterapkan. Penegakan hukum berasal dari masyarakat, dan bertujuan untuk mencapai kedamaian di dalam masyarakat. Partisipasi masyarakat yang aktif dalam pengawasan oranag asing di suatu wilayah Indonesia sangat membantu dalam penegakan hukum. Partisipasi dapat diwujudkan dalam hal laporan kepada pejabat terdekat yang ada di sekitar wilayah tersebut. Masyarakat dapat melaporkan keberadaan dan kegiatan orang asing sesuai PP 13 Tahun 2013 yang menyebutkan setiap orang yang memberikan kesempatan orang asing menginap di tempat kediamannya wajib melaporkan kepada Kantor Kepolisian Republik Indonesia atau Pejabat Pemerintah Daerah setempat dalam jangka waktu 24 (dua puluh empat) jam sejak tanggal kedatangan orang asing tersebut.

Pasal tersebut dikuatkan dengan pernyataan Ryan Aditya sebagai Kepala Subseksi Pengawasan yang mengatakan bahwa :

"Orang asing yang tinggal di suatu wilayah Indonesia, wajib melapor keberadaannya ke Ketua Rukun Tetangga (RT) atau Rukun Warga (RW) setempat, selanjutnya oleh Ketua RT/RW keberadaan orang asing dilaporkan ke kecamatan, dan kelurahan. Selanjutnya kelurahan memberikan laporan ke Kantor Imigrasi dan Kantor Polisi setempat untuk data pengawasan dengan mengisi Kartu Imigrasi yang berisikan identitas lengkap, nomor passpor, nomor visa, dan tujuannya datang ke Indonesia" (Wawancara, 14 April 2015).

Selain partisipasi dari masyarakat, ada partisipasi khusus yang sangat penting terhadap keberadaan orang asing di wilayah Indonesia. Penjamin atau sponsor adalah seseorang yang bertanggung jawab terhadap keberadaan dan kegiatan orang asing selama di Indonesia. Pasal 63 ayat (1) yang menyebutkan orang asing tertentu yang berada di Wilayah Indonesia wajib memiliki Penjamin yang menjamin keberadaannya. Penjamin juga berkewajiban melaporkan setiap perubahan status sipil, status keimigrasian, dan perubahan alamat orang asing.

Pasal tersebut diperkuat dengan pernyataan Ryan Aditya sebagai Kepala Subseksi Pengawasan yang mengatakan :

"Penjamin harus aktif terhadap keberadaan dan kegiatan orang asing agar tidak melanggar izin tinggal (overstay)" (Wawancara, 14 April 2015).

Dengan kerja sama antara penegak hukum/pejabat imigrasi dengan instansi terkait dan partisipasi masyarakat, dapat meminimalkan angka pelanggaran administrasi keimigrasian di wilayah Indonesia

Faktor yang terakhir yaitu faktor kebudayaan, yakni sebagai hasil karya, cipta, dan rasa yang didasarkan pada karsa manusia di dalam pergaulan hidup. Kebudayaan Indonesia mempunyai daya tarik tersendiri. Kebudayaan masyarakat Indonesia yang ramah menyebabkan banyak wisatawan mancanegara datang ke Indonesia, karena Indonesia terdiri atas berbagai suku bangsa terdapat bermacam ragam kebudayaannya seperti bangunan rumah adat, batik, ukiran Jepara, tari-tarian, upacara adat perkawinan, dan sikap masyarakat Indonesia yang terkenal ramah (Supramono, 2012:2).

Pengawasan yang dilakukan oleh Pejabat Imigrasi di Kantor Imigrasi Kelas I Semarang telah sesuai dengan Undang-Undang Nomor 6 Tahun 2011 Pasal 66 ayat (2) dan melibatkan instansi terkait seperti Kepolisian Republik Indonesia, Pemerintah Kabupaten dan Kota, dan Dinas Ketenagakerjaan Transmigrasi Kota Semarang serta partisipasi masyarakat. Pengawasan yang dilakukan oleh pejabat imigrasi lebih ditekankan secara administrasi pada saat orang asing akan masuk dan keluar wilayah Indonesia.

\section{2) Faktor Penghambat}

Penegakan hukum di Kantor Imigrasi Kelas I Semarang terhadap warga negara asing 
(WNA) yang melanggar izin tinggal terkadang menemui kendala yang bersifat menghambat. Meskipun demikian demi menegakan hukum keimigrasian Kantor Imigrasi Kelas I Semarang selalu mengupayakan agar penegakan hukum dapat berjalan secara efektif. Faktor-faktor penghambat dalam menegakan hukum di Kantor Imigrasi Kelas I Semarang diantaranya adalah :

Pertama yaitu faktor sarana atau fasilitas, yang mendukung penegakan hukum mencakup tenaga manusia yang berpendidikan dan terampil, organisasi yang baik, peralatan yang memadai, keuangan yang cukup, dan seterusnya. Wilayah kerja Kantor Imigrasi Kelas I Semarang yang terdiri dari 2 (dua) kota yaitu kota Semarang (16 kecamatan) dan kota Salatiga (4 kecamatan), dan 5 (lima) kabupaten yang terdiri dari kabupaten Semarang di Ungaran (15 kecamatan), kabupaten Kudus (9 kecamatan), kabupaten Demak (14 kecamatan), kabupaten Purwodadi (19 kecamatan), dan kabupaten Kendal (17 kecamatan) dengan jumlah seluruh kecamatan yaitu sebanyak 94 kecamatan. Kantor Imigrasi tidak sama dengan Kepolisian yang wujudnya ada sampai di sektor. Kantor Imigrasi bekerja berdasarkan zona yaitu kabupaten dan kota yang sifatnya rutin. Per kabupaten setiap bulan dilakukan pemetaan untuk pengumpulan data.

Kedua yaitu faktor penegak hukum yakni pihak-pihak yang secara langsung berkecimpung dalam bidang penegakan hukum. Kantor Imigrasi Kelas I Semarang yang menjadi penegak hukum yaitu pejabat imigrasi itu sendiri. Dapat dikatakan bahwa secara kuantitas jumlah tim pengawasan dan penindakan di Kantor Imigrasi Kelas I Semarang kurang memadai, karena banyaknya jumlah orang asing yang datang ke wilayah Jawa Tengah sehingga menyebabkan ketidak seimbangan dengan penegak hukum. Tim pengawasan dan penindakan orang asing secara struktural terdiri dari 1 (satu) Kepala Seksi Pengawasan dan Penindakan Keimigrasian, 1 (satu) Kepala Subseksi Pengawasan Keimigrasian, dan 1 (satu) Kepala Subseksi Penindakan Keimigrasian. Jumlah personil di bagian pengawasan orang asing sebanyak 3 (tiga) personil dan bagian penindakan keimigrasian sebanyak
3 personil. Kekurangan personil ini terjadi hampir di seluruh Kantor Imigrasi yang ada di Indonesia.

Kantor Imigrasi Kelas I Semarang jika dilihat dari segi sumber daya manusia yaitu mutu dan kualitasnya maka Kantor Imigrasi Kelas I Semarang dapat dikatakan telah memenuhi standar mutu sumber daya manusia yang baik, dimana para tim pengawasan dan penindakan di Kantor Imigrasi Kelas I Semarang rata-rata berpendidikan Strata-1. Dilihat dari jumlah sumber daya manusia dari tim pengawasan dan penindakan Kantor Imigrasi Kelas I Semarang masih kurang memadai, sehingga tim pengawasan dan penindakan terkadang sedikit terkendala karena jumlah dari tim pengawasan dan penindakan tidak seimbang dengan jumlah warga negara asing (WNA) yang datang ke wilayah Jawa Tengah khususnya Semarang.

\section{Simpulan}

Berdasarkan hasil penelitian ini dapat disimpulkan sebagai berikut : Pertama, penegakan hukum terhadap orang asing yang melanggar izin tinggal (overstay) di Kantor Imigrasi Kelas I Semarang telah sesuai dengan undang-undang yang mengatur mengenai keimigrasian, yaitu Undang-Undang Nomor 6 Tahun 2011 dan Peraturan Pemerintah Nomor 31 Tahun 2013 tentang Peraturan Pelaksanaan Undang-Undang Nomor 6 Tahun 2011. Penegakan hukum dilaksanakan oleh bagian penegak hukum di Kantor Imigrasi Kelas I Semarang saat ditemukan pelanggaran administratif keimigrasian setelah dilakukan pemeriksaan kelengkapan administratif orang asing, dengan memberikan tindakan administratif yang berupa pengenaan biaya beban atau deportasi. Biaya beban dikenakan sebesar Rp 300.000,00 per hari, sedangkan biaya yang timbul pada saat orang asing dideportasi ditanggung oleh penjaminnya. Kantor Imigrasi Kelas I Semarang telah memberikan tindakan administratif berupa pengenaan biaya beban pada periode 2013 dengan jumlah keseluruhan denda overstay sebesar Rp \pm 400.000.000,00, periode 2014 sebesar Rp 482.000.000,00, dan periode Januari sampai dengan 28 April 2015 sebe- 
sar Rp 130.500.000,00. Jumlah WNA yang melanggar izin tinggal overstay sebanyak 402 orang, sedangkan deportasi pada tahun 2013 sampai dengan tahun 2015 sebanyak 17 orang.

Kedua, faktor-faktor yang mempengaruhi penegakan hukum terhadap WNA di kota Semarang yaitu adanya faktor pendukung dan faktor penghambat. Faktor pendukung dalam penegakan hukum di Kantor Imigrasi Kelas I Semarang yaitu Seksi Penindakan keimigrasian di Semarang bekerja sama dengan instansi terkait seperti Kepolisian Republik Indonesia, Pemerintah Kabupaten dan Kota, Dinas Ketenagakerjaan dan Transmigrasi Kota Semarang, dan Polisi Resor Kota Besar Semarang beserta jajarannya selaku koordinator pengawasan orang asing.

Faktor penghambat bagi Kantor Imigrasi Kelas I Semarang dalam mewujudkan penegakan hukum yaitu kurangnya sumber daya manusia (SDM) dalam hal kuantitas, sehingga menimbulkan ketidak seimbangan antara penegak hukum dengan jumlah orang asing yang datang ke Jawa Tengah terkait wilayah kerja Kantor Imigrasi Kelas I Semarang.

\section{Daftar Pustaka}

Amiruddin dan Zainal Asikin. 2013. Pengantar Metode Penelitian Hukum. Jakarta: Rajawali Pers.

Faizal, Eka Rendytia. 2013. (Skripsi). Peran dan Fungsi Kantor Wilayah Kementerian Hukum dan HAM Jawa Tengah Dalam Melaksanakan Pengawasan dan Penindakan Keimigrasian Terhadap Orang Asing di Indonesia (Studi di Kantor Wilayah Kementerian Hukum dan HAM Jawa Tengah). FH Unnes. Semarang.

Fakultas Hukum UNNES. 2015. Pedoman Penulisan Skripsi Fakultas Hukum. Semarang: Fakulatas Hukum UNNES.

Linardi, Brigitta Amelia. 2013. (Skripsi). Perancangan Buku Esai Fotografi Mengenai Gambang Semarang Art Company. Universitas Kristen Petra. Surabaya.

Rahardjo, Satjipto. 2009. Masalah Penegakan Hukum Suatu Tinjauan Sosiologis. Bandung: CV Sinar Baru.

Robiyansah, Muhammad. 2012. (Skripsi). Efektifitas Pengawasan Izin Tinggal Tenaga Kerja Asing di Wilayah kerja Kantor Imigrasi Kelas I Samarinda.
Universitas Mulawarman. Samarinda.

Safaat, Najarudin. 2008. (Thesis). Analisis Penegakan Hukum Keimigrasian Pada Kantor Imigrasi Klas I Khusus Soekarno Hatta Berdasarkan UndangUndang Keimigrasian dan Hukum Acara Pidana. Universitas Indonesia. Depok.

Sjahriful, Abdullah. 1993. Memperkenalkan Hukum Keimigrasian. Jakarta : Ghalia.

Soejono dan Abdurrahman. 2005. Metode Penelitian Suatu Pemikiran dan Penerapan. Jakarta : PT Rineka Cipta dan PT Bina Adiaksara.

Soekanto, Soerjono. 2014. Faktor-faktor yang Mempengaruhi Penegakan Hukum. Jakarta : PT. RajaGrafindo Persada.

Soemitro, Ronny Hanitijo. 1988. Metodologi Penelitian Hukum dan Jurimetri. Jakarta Timur : Ghalia Indonesia.

Soetoprawiro, Koerniatmanto. 1994. Hukum Kewarganegaraan dan Keimigrasian Indonesia. Jakarta: Gramedia Pustaka Utama.

Supramono, Gatot. 2012. Hukum Orang Asing di Indonesia. Jakarta Timur : Sinar Grafika.

Saleh, John Sarodja. 2008. Sekuriti dan Inteligen Keimigrasian : hasil suatu kajian tim : doktrin intelijen keimigrasian. Jakarta : Direktorat Jenderal Imigrasi Departemen Hukum dan HAM.

Ukun, Wahyudin. 2004. Deportasi Sebagai Instrumen Penegakan Hukum dan Kedaulatan Negara di Bidang Keimigrasian. Jakarta: AKA Press.

Undang-Undang Dasar Negara Republik Indonesia Tahun 1945

Undang-Undang Nomor 6 Tahun 2011

Peraturan Pemerintah Nomor 13 Tahun 2013

Peraturan Pemerintah Nomor 45 Tahun 2014

Peraturan Pemerintah Nomor 38 Tahun 2005

AIESEC, 2015. https://aiesec.or.id. Diakses tanggal 15 Juni 2015 Pukul 20.30 WIB.

Kompas.com. 2015. Semarang, Jejak Little Netherland. http://travel.kompas.com/ $\mathrm{read} / 2013 / 10 / 03 / 1053467 /$ Semarang.Jejak. Little.Netherland. Diakses tanggal 1 Juni 2015 Pukul 20.10 WIB.

Unilever, 2015. https://id.wikipedia.org/wiki/Unilever. Diakses tanggal 15 Juni 2015 Pukul 20.15 WIB.

US Embassy, 2012. http://indonesian.jakarta.usembassy.gov. Diakses tanggal 15 Juni 2015 Pukul $21.00 \mathrm{WIB}$. 